\title{
Study of Lipid Profile in Patients of Hypothyroidism And Correlation with Incidence of Gallstone
}

\author{
${ }^{1}$ Dr.Archana Gupta, ${ }^{2}$ Dr.Neeti Agrawal, ${ }^{3}$ Dr.Saras Sondhiya. \\ ${ }^{1}$ Associate Professor, ${ }^{2,3}$ P.G. Student \\ Department of Medicine, G.R. Medical College, Gwalior (M.P.)
}

\begin{abstract}
Background: Thyroid hormones influences lipid metabolism, rise in serum cholesterol in hypothyroidism causes supersaturation of bile leading to depressed gall bladder contractility, hence risk of gall stone formation so we tries to correlate these changes.

Material and methods: The present study has been conducted in Department of Medicine, J.A. Group of Hospitals, G.R. Medical College, Gwalior (M.P.) from period of January 2011 to January 2012. Present study comprised of 105 patients with hypothyroidism attending OPD and medicine ward. They were examined thoroughly after history taking and then subjected to routine investigation with special emphasis on lipid profile, thyroid profile and USG abdomen especially gall bladder and hepatobiliary. Association of gall bladder stone and hypothyroidism was also observed. Patients with TSH level > 5.5 were considered to having hypothyroidism, thus cases were divided into two groups. Group I with TSH level between 5.5 to $10 \mu \mathrm{IU} / \mathrm{ml}$ (Subclinical hypothyroidism) and Group II with TSH level above $10 \mu \mathrm{IU} / \mathrm{ml}$ (Overt hypothyroidism).

Results: Prevalence of hypothyroidism was maximum between 20-60 years age group patients (77.23\%). Most cases occurred in females ( 82 females and 23 males). Most common symptoms in female was tiredness (58 i.e. $70.73 \%)$ then weight gain (52 i.e. 63.41\%), cold intolerance (47 i.e. 57.31\%), constipation. Most common sign dry coarse skin (79.26\%) followed by edema (67.0\%). While in male patients most common symptom is tiredness (16 i.e. 69.56\%) followed by cold intolerance (11 i.e. 47.82\%), weight gain (10 i.e. 43.47\%). Most common sign was edema (69.56\%) and then dry coarse skin (60.86\%). These clinical features were more in overt hypothyroidism compared to subclinical hypothyroidism in both sexes. Abnormal lipid profile was seen in both overt hypothyroidism (29/49 i.e. 59.18\%) and subclinical hypothyroidism patients (28/56 i.e. 50\%). Abnormal total cholesterol, TG, LDL, VLDL was seen in $35.1 \%, 27.0 \%, 8.1 \%$ and $13.5 \%$ respectively in overt hypothyroidism female patients while in subclinical hypothyroidism female patients it was $28.8 \%, 24.4 \%, 8.8 \%$, $11.1 \%$ and $15.5 \%$ respectively. There is significant increase in total cholesterol and LDL cholesterol and decrease in HDL cholesterol. Prevalence of cholelithiasis was more in subclinical hypothyroidism compared to overt hypothyroidism which was $15 / 56(26.78 \%)$ and $7 / 49$ (14.28\%) respectively, that too more in female compared to male, thus showing strong association between them.
\end{abstract}

Conclusion: Hypothyroidism is associated with dyslipidemia, cholelithiasis is significantly associated with subclinical hypothyroidism.

Keywords: Subclinical hypothyroidism, overt hypothyroidism, lipid profile, cholelithiasis

\section{Introduction}

Hypothyroidism is a common endocrinological disorder, its clinical presentation is variable but well established. Hypothyroidism is a clinical state resulting from an insufficient amount of circulatory thyroid hormones to support normal body function. It may exist in utero or develop in infancy, childhood or even in adult life. The prevalence of unsuspected overt hypothyroidism, defined as the combination of biochemical and clinical findings of hypothyroidism. The clinical manifestations of hypothyroidism are variable, depending upon its course, duration and severity. The spectrum extends from subclinical to overt hypothyroidism to myxedema coma. The classic changes is the slowing of physical and mental activities and of all the body systems ${ }^{3}$. The characteristic pathological findings in a hypothyroid patients is the accumulation of hyaluronic acid and other glycoaminoglycons in the interstitial tissues ${ }^{2}$. The objectives of this study were to look at the presenting clinical features of hypothyroidism. Hypothyroidism refers to a condition in which the amount of thyroid hormones in the body is below normal. However some patients with mild hypothyroidism may note improvement in their sense of well being after being treated with thyroid hormone.

Patient with early disease usually have none or minimal clinical signs (subclinical hypothyroidism) although hypothyroidism may be instantly recognizable, in the present study, a group of patients with different grades of overt and subclinical hypothyroidism were studied to assess there liability of existing clinical and pathological parameters to confirm hypothyroid state. The term subclinical may be inaccurate as some of the patients have symptoms. 
Thyroid hormone has multiple effects on liver function including stimulation of enzymes regulating lipogenesis and lipolysis as well as oxidative processes ${ }^{2}$. It regulates the gene expression of a range of cellular pathways and function such as gluconeogenesis, lipogenesis, insulin signaling, adenylate cyclase, signaling, cell proliferation and apoptosis. The patients of hypothyroidism had significant higher levels of serum cholesterol ${ }^{4}$. The HDL levels were comparatively lower in the thyroid patients. It can be concluded that hypothyroidism is associated with dyslipidemia i.e. increased total cholesterol and LDL cholesterol level and increased risk for the development of atherosclerosis in hypothyroid patients in Indian population.

It has been reported recently that the prevalence of subclinical hypothyroidism is commoner in subjects with common bile duct (CBD) stones. It has been estimated that the prevalence of subclinical hypothyroidism is more than $11 \%$ among women over 60 years having CBD stones. It has been reported that the occurrence of hypothyroidism is higher in subjects with CBD stones, when compared with subjects having gallstones as well as normal subjects. ${ }^{1}$ Hypothyroidism is associated with slow bile flow, and this in combination with the increased biliary cholesterol load, and the reduced hepatocyte excretion rate, may partially explain the increased predilection for CBD stones in hypothyroid patients.

\section{Material And Methods}

This open prospective study was conducted in the Department of Medicine, G.R. Medical College \& J.A. Group of Hospital, Gwalior (M.P.), India. This study comprised of 105 patients with hypothyroidism attending OPD and Medicine Ward, J.A.H. and Kamla Raja Hospital, Gwalior (M.P.) India from period of January 11 to January 2012.

\section{The patients enrolled in the study as per the inclusion \& exclusion criteria -}

(A) Inclusion Criteria -

$>$ Patients who are diagnosed with deranged thyroid hormone levels.

(B) Exclusion criteria -

$>$ Patient receiving lipid lowering drugs.

$>$ Acute illness

\section{Method}

All the patients with hypothyroidism attending O.P.D. or ward in J.A. Group of Hospital were included on subjects. They were examined thoroughly after history taking and then subjected to routine investigations with special emphasis on lipid profile, thyroid profile and USG abdomen especially gall bladder and hepatobiliary. Association of gall bladder stone and hypothyroidism with comorbid diseases like hypertension, diabetes mellitus, coronary artery disease was also be observed. Patients with TSH levels above $5.5 \mu \mathrm{IU} / \mathrm{ml}$ were considered to be having hypothyroidism. As per serum TSH level the cases were divided into two groups.

Group I : Subclinical hypothyroidism - TSH level 5.5 to $10 \mu \mathrm{IU} / \mathrm{ml}$

Group II : Overt hypothyroidism - TSH level above then $10 \mu \mathrm{IU} / \mathrm{ml}$.

\section{Result}

Prevalence of hypothyroidism was maximum between 20-60 years age group patients (77.23\%). Most cases occurred in females ( 82 females and 23 males). Most common symptoms in female was tiredness (58 i.e. $70.73 \%$ ) then weight gain (52 i.e. $63.41 \%$ ), cold intolerance (47 i.e. $57.31 \%$ ), constipation. Most common sign dry coarse skin $(79.26 \%)$ followed by edema $(67.0 \%)$. While in male patients most common symptom is tiredness (16 i.e. $69.56 \%$ ) followed by cold intolerance (11 i.e. $47.82 \%)$, weight gain (10 i.e. $43.47 \%)$. Most common sign was edema $(69.56 \%)$ and then dry coarse skin $(60.86 \%)$. These clinical features were more in overt hypothyroidism compared to subclinical hypothyroidism in both sexes. Abnormal lipid profile was seen in both overt hypothyroidism (29/49 i.e. 59.18\%) and subclinical hypothyroidism patients (28/56 i.e. 50\%). Abnormal total cholesterol, TG, LDL, VLDL was seen in $35.1 \%, 27.0 \%, 8.1 \%$ and $13.5 \%$ respectively in overt hypothyroidism female patients while in subclinical hypothyroidism female patients it was $28.8 \%, 24.4 \%, 8.8 \%$, $11.1 \%$ and $15.5 \%$ respectively. There is significant increase in total cholesterol and LDL cholesterol and decrease in HDL cholesterol. Prevalence of cholelithiasis was more in subclinical hypothyroidism compared to overt hypothyroidism which was $15 / 56(26.78 \%)$ and $7 / 49$ (14.28\%) respectively, that too more in female compared to male, thus showing strong association between them.

Among comorbid diseases, in subclinical hypothyroidism, in age group, $>60$ or more, male patients predominantly suffer from hypertension and coronary artery disease and same age group female predominantly suffer from hypertension. 
Table No. 1 Age \& Sex wise distribution of hypothyroidism patient

\begin{tabular}{|c|c|c|c|c|c|c|}
\hline \multirow{2}{*}{ Age groups (in yrs) } & \multicolumn{2}{|c|}{ Male } & \multicolumn{2}{c|}{ Female } & \multicolumn{2}{c|}{ Total } \\
\cline { 2 - 7 } & No. & $\mathbf{\%}$ & No. & \% & No. & \% \\
\hline$<20$ & 00 & 00 & 04 & 3.81 & 4 & 3.81 \\
\hline $21-40$ & 06 & 5.71 & 40 & 38.1 & 46 & 43.81 \\
\hline $41-60$ & 10 & 9.52 & 25 & 23.81 & 35 & 33.33 \\
\hline$>60$ & 07 & 6.67 & 13 & 12.38 & 20 & 19.05 \\
\hline Total & $\mathbf{2 3}$ & $\mathbf{2 1 . 0 9}$ & $\mathbf{8 2}$ & $\mathbf{7 8 . 1}$ & $\mathbf{1 0 5}$ & $\mathbf{1 0 0}$ \\
\hline
\end{tabular}

Table No. 2 All patients are divided into two groups according with TSH level

1. Sub clinical hypothyroidism (TSL level 5.5 to $10 \mu \mathrm{IU} / \mathrm{ml}$ )

2. Overt hypothyroidism (TSH level above the $10 \mu \mathrm{IU} / \mathrm{ml}$ )

\begin{tabular}{|c|c|c|c|c|c|c|c|c|c|c|c|c|}
\hline Age & \multicolumn{6}{|c|}{ Sub clinical hyperthyroidism } & \multicolumn{6}{|c|}{ Overt hypothyroidism } \\
\hline $\mathbf{p}$ & \multicolumn{2}{|c|}{ Male } & \multicolumn{2}{|c|}{ Female } & \multicolumn{2}{|c|}{ Total } & \multicolumn{2}{|c|}{ Male } & \multicolumn{2}{|c|}{ Female } & \multicolumn{2}{|c|}{ Total } \\
\hline (yrs) & No. & $\%$ & No. & $\%$ & No. & $\%$ & No. & $\%$ & No. & $\%$ & No. & $\%$ \\
\hline$<20$ & 00 & 00 & 03 & 2.86 & 3 & 2.86 & 00 & 00 & 01 & 0.95 & 1 & 0.95 \\
\hline $21-40$ & 04 & 3.81 & 21 & 20 & 25 & 23.81 & 02 & 1.9 & 19 & $\begin{array}{c}18.1 \\
0\end{array}$ & 21 & 20 \\
\hline $41-60$ & 04 & 3.81 & 14 & $\begin{array}{c}13.3 \\
3\end{array}$ & 18 & 17.14 & 06 & 5.71 & 11 & $\begin{array}{c}10.4 \\
8\end{array}$ & 17 & $\begin{array}{c}16.1 \\
9\end{array}$ \\
\hline$>60$ & 03 & 2.86 & 07 & 6.67 & 10 & 9.52 & 04 & 3.81 & 06 & 5.71 & 10 & 9.52 \\
\hline Total & 11 & 10.48 & 45 & $\begin{array}{c}42.8 \\
6\end{array}$ & 56 & 53.33 & 12 & 11.43 & 37 & $\begin{array}{c}35.2 \\
4\end{array}$ & 49 & $\begin{array}{c}46.6 \\
7\end{array}$ \\
\hline
\end{tabular}

Subclinical hypothyroidism female are the most common.

Table No. 3

Age wise distribution of dyslipidemia in total subclinical and overt hypothyroidism male/female patient

\begin{tabular}{|c|c|c|c|c|c|c|}
\hline $\begin{array}{c}\text { Age group } \\
\text { (in yrs) }\end{array}$ & $\begin{array}{c}\text { Total } \\
\text { subclinical } \\
\text { male+ } \\
\text { female }\end{array}$ & $\begin{array}{c}\text { Dysli- } \\
\text { pidemia }\end{array}$ & $\%$ & $\begin{array}{c}\text { Total overt } \\
\text { male+ } \\
\text { female }\end{array}$ & $\begin{array}{c}\text { Dysli- } \\
\text { pidemia }\end{array}$ & $\%$ \\
\hline$<20$ & 03 & 0 & 00 & 01 & 0 & 0 \\
\hline $21-40$ & 25 & 08 & 32 & 21 & 08 & 38.09 \\
\hline $41-60$ & 18 & 11 & 61.11 & 17 & 13 & 76.4 \\
\hline$>60$ & 10 & 09 & 90 & 10 & 8 & 80 \\
\hline Total & $\mathbf{5 6}$ & $\mathbf{2 8}$ & $\mathbf{5 0}$ & $\mathbf{4 9}$ & $\mathbf{2 9}$ & $\mathbf{5 9 . 1 8}$ \\
\hline
\end{tabular}

Table No. 4 Abnormalities of lipid profile in total male and female hypothyroidism patient

\begin{tabular}{|l|c|c|c|c|}
\hline \multirow{2}{*}{ Lipid profile } & \multicolumn{2}{|c|}{ Male(n=23) } & \multicolumn{2}{c|}{ Female(n=82) } \\
\cline { 2 - 5 } & No. & \% & No. & \% \\
\hline $\begin{array}{l}\text { Total cholesterol (150-250 } \\
\text { mg\%) }\end{array}$ & 08 & 34.7 & 26 & 31.7 \\
\hline $\begin{array}{l}\text { Triglyceride } \\
(60-150 \mathrm{mg} \%)\end{array}$ & 07 & 30.4 & 21 & 25.6 \\
\hline $\begin{array}{l}\text { HDL } \\
(36-60 \mathrm{mg} \%)\end{array}$ & 04 & 17.3 & 15 & 18.2 \\
\hline $\begin{array}{l}\text { LDL } \\
\text { (Upto } 130 \mathrm{mg} \%)\end{array}$ & 02 & 8.6 & 07 & 8.5 \\
\hline $\begin{array}{l}\text { VLDL } \\
(12-30 \mathrm{mg} \%)\end{array}$ & 08 & 34.7 & 10 & 12.1 \\
\hline
\end{tabular}

Table No. 5 Abnormalities of lipid profile in total no. of subclinical and overt female hypothyroidism patient $(\mathrm{n}=82)$

\begin{tabular}{|l|c|c|c|c|}
\hline \multirow{2}{*}{ Lipid profile } & \multicolumn{2}{|c|}{ Subclinical (45) } & \multicolumn{2}{c|}{ Overt (37) } \\
\cline { 2 - 5 } & No. & \% & No. & 35.1 \\
\hline $\begin{array}{l}\text { Total cholesterol (150-250 } \\
\text { mg\%) }\end{array}$ & 13 & 28.8 & 13 & 27 \\
\hline $\begin{array}{l}\text { Triglyceride } \\
(60-150 \mathrm{mg} \%)\end{array}$ & 11 & 24.4 & 10 & 21.6 \\
\hline $\begin{array}{l}\text { HDL } \\
(36-60 \mathrm{mg} \%)\end{array}$ & 07 & 15.5 & 08 & 8.1 \\
\hline $\begin{array}{l}\text { LDL } \\
(\text { Upto } 130 \mathrm{mg} \%)\end{array}$ & 04 & 8.8 & 03 & \\
\hline
\end{tabular}




\begin{tabular}{|l|c|c|c|c|}
\hline $\begin{array}{l}\text { VLDL } \\
(12-30 \mathrm{mg} \%)\end{array}$ & 05 & 11.1 & 05 & 13.5 \\
\hline
\end{tabular}

Table No. 6 Abnormalities of lipid profile in total no. of subclinial and overt male

\begin{tabular}{|l|c|c|c|c|}
\hline \multicolumn{1}{|c|}{ Lipid profile } & \multicolumn{2}{|c|}{ Subclinical (11) } & \multicolumn{2}{c|}{ Overt (12) } \\
\cline { 2 - 5 } & No. & \% & No. & \% \\
\hline $\begin{array}{l}\text { Total cholesterol (150-250 } \\
\mathrm{mg} \%)\end{array}$ & 05 & 45.45 & 03 & 25 \\
\hline $\begin{array}{l}\text { Triglyceride } \\
(60-150 \mathrm{mg} \%)\end{array}$ & 05 & 45.45 & 02 & 16.6 \\
\hline $\begin{array}{l}\text { HDL } \\
(36-60 \mathrm{mg} \%)\end{array}$ & 02 & 18.18 & 02 & 16.6 \\
\hline $\begin{array}{l}\text { LDL } \\
(\text { Upto } 130 \mathrm{mg} \%)\end{array}$ & 02 & 18.18 & 00 & 00 \\
\hline $\begin{array}{l}\text { VLDL } \\
(12-30 \mathrm{mg} \%)\end{array}$ & 04 & 36.36 & 04 & 33.33 \\
\hline
\end{tabular}

Table No. 7 Age wise distribution of subclinical hypothyroidism male/female patient in which gall stone present and h/o cholecystectomy

\begin{tabular}{|c|c|c|c|c|c|c|c|c|c|c|}
\hline \multirow{2}{*}{$\begin{array}{l}\text { Age } \\
\text { group } \\
\text { (in } \\
\text { yrs) }\end{array}$} & \multirow[b]{2}{*}{$\begin{array}{c}\text { Total } \\
\text { (no. } \\
\text { of pt.) }\end{array}$} & \multicolumn{4}{|c|}{ Sub-clinical male $(n=11)$} & \multirow[b]{2}{*}{$\begin{array}{c}\text { Total } \\
\text { (no } \\
\text { of } \\
\text { pt..) }\end{array}$} & \multicolumn{4}{|c|}{ Subclinical female $(n=45)$} \\
\hline & & $\begin{array}{c}\text { Gall } \\
\text { stone } \\
\text { present }\end{array}$ & $\begin{array}{c}\text { H/o } \\
\text { cholecyst } \\
\text { ectomy }\end{array}$ & $\stackrel{\bar{\pi}}{\stackrel{0}{\theta}}$ & $\%$ & & $\begin{array}{c}\text { Gall } \\
\text { stone } \\
\text { present }\end{array}$ & $\begin{array}{c}\mathrm{H} / \mathrm{o} \\
\text { cholecyste } \\
\text { ctomy }\end{array}$ & है & $\%$ \\
\hline$<20$ & 00 & 00 & 00 & 00 & 00 & 03 & 00 & 00 & 00 & 00 \\
\hline $21-40$ & 04 & 00 & 00 & 00 & 00 & 21 & 01 & 00 & 01 & 2.2 \\
\hline $41-60$ & 04 & 01 & 00 & 01 & 9.09 & 14 & 06 & 02 & 08 & 17.17 \\
\hline$>60$ & 03 & 00 & 01 & 01 & 9.09 & 07 & 03 & 01 & 04 & 8.8 \\
\hline Total & 11 & 01 & 01 & $\mathbf{0 2}$ & $\begin{array}{c}18.1 \\
8\end{array}$ & 45 & 10 & $\mathbf{0 3}$ & 13 & 28.8 \\
\hline
\end{tabular}

\begin{tabular}{|c|c|c|c|c|c|c|c|c|c|c|}
\hline \multirow{2}{*}{$\begin{array}{c}\text { Age } \\
\text { group } \\
\text { (in yrs) }\end{array}$} & & \multicolumn{4}{|c|}{ Overt male $(n=12)$} & & \multicolumn{4}{|c|}{ Overt female $(n=37)$} \\
\hline & $\begin{array}{l}\text { Total } \\
\text { (no. } \\
\text { of pt.) }\end{array}$ & $\begin{array}{c}\text { Gall } \\
\text { stone } \\
\text { present }\end{array}$ & $\begin{array}{c}\text { H/o } \\
\text { cholecyst } \\
\text { ectomy }\end{array}$ & ๘ี & $\%$ & $\begin{array}{c}\text { Total } \\
\text { (no. } \\
\text { of } \\
\text { pt.) }\end{array}$ & $\begin{array}{c}\text { Gall } \\
\text { stone } \\
\text { prese } \\
\text { nt }\end{array}$ & $\begin{array}{c}\mathrm{H} / \mathrm{o} \\
\text { cholecyst } \\
\text { ectomy }\end{array}$ & ڤే & $\%$ \\
\hline$<20$ & 00 & 00 & 00 & 00 & 00 & 01 & 00 & 00 & 00 & 00 \\
\hline $21-40$ & 02 & 00 & 00 & 00 & 00 & 19 & 00 & 00 & 00 & 00 \\
\hline $41-60$ & 06 & 00 & 00 & 00 & 00 & 11 & 03 & 01 & 04 & 10.8 \\
\hline$>60$ & 04 & 00 & 00 & 00 & 00 & 06 & 03 & 00 & 03 & 8.1 \\
\hline Total & 12 & 00 & $\mathbf{0 0}$ & 00 & $\mathbf{0 0}$ & 37 & 06 & 01 & $\mathbf{0 7}$ & 18.9 \\
\hline
\end{tabular}

Table No. 8 Age wise distribution of overt hypothyroidism male/female patient in which gall stone present and h/o cholecystectomy

\section{Discussion}

Subclinical hypothyroidism may develop insidiously as compared to the overt hypothyroidism.

Sex Distribution-

In the present study we found the female preponderance in hypothyroidism. The female to male ratio was 4:1 $(82: 23)$ ( $p$ value $<0.05$ ) which is similar to Khurram et al $(\mathbf{2 0 0 3})^{5}$ study of clinical presentation of hypothyroidism.

Both subclinical and overt hypothyroidism was seen mainly in female compared to male patients which was 45:11 and 37:12 respectively similar to Samanta B.B et al $^{6}$ study of clinical profile of hypothyroidism and found that Most cases occur in the females

Age Distribution-

The present study show that prevalence of hypothyroidism was maximum between 20 to $60 \mathrm{yrs}$ middle age group patients $81(77.23 \%$ ) and in over $60 \mathrm{yr}$ age group is $19.05 \%$ (20) similar result was also found in study of Wright-Rascose RA et al (2010) ${ }^{7}$ found mean age of hypothyroidism was 43.3 yrs (range 12-82 year). Most cases occurred in the females and the most common age of onset was in the 21-60 years of age group similar to other studies which is statistically significant ( $\mathrm{p}$ value $<0.05$ ). 


\section{Clinical Feature-} Symptom-

In present study most common symptom in female was tiredness and $70.73 \%(58)$. Khurram et al (2003) $^{\mathbf{5}}$ then weight gain $63.41 \%(52)$, cold intolerance $57.31 \%(47)$, constipation, menstrual irregularity, lethargy is $42.68 \%$ (35), and abdominal pain in 30.48\%(25), hoarseness of voice $24.39 \%(20)$ while in male patients most common symptom is tiredness $69.56 \%$ (16) followed by cold intolerance $47.82 \%(11)$, weight gain $43.47 \%(10)$, constipation $39.13 \%(9)$, hoarseness of voice $17.39 \%(4)$, abnormal eye dropping $8.69 \%$ (2), abdominal pain $1.8 .69 \%$ (2). Our result was similar to Lahiri et al (1996) ${ }^{\mathbf{8}}$ in their series of 128 hypothyroid female it was found that oligomenorrhoea was the commonest menstrual abnormality and next common was menorrhagia.

Signs-

In present study most common sign in male was oedema 69.56\%(16 ) and then dry coarse skin $60.86 \%$ (14), pallor $26.0 \%$ (6), bradycardia $21.73 \%(5)$, cyanosis $21.73 \%$ (5), anaemia $17.39 \%$ ( 4) ,icterus $13.04 \%$ (3) while in female. Dry coarse skin is the most common sign 79.26\%(65) followed by oedema $67.0 \%$ (55), bradycardia $24.39 \%(20)$, pallor $23.17 \%(19)$, cyanosis $21.95 \%$ (18), anaemia $19.51 \%$ (16) and then icterus $19.51 \%(16)$.

In presenting study we found that $21.95 \%$ patients having cyanosis. Main causative factor for cyanosis was pulmonary artery hypertension due to other related autoimmune disorder associated with hypothyroidism. In presenting study Both sign and symptom was more in overt hypothyroidism compare to subclinical hypothyroidism in both male and female which was similar to Samanta B B et al. ${ }^{6}$

\section{Hypothyridism And Dyslipidemia}

In present study we found that abnormal lipid profile seen in both in subclinical and overt hypothyroidism patients but it was more deranged in overt hypothyroidism patients compare to subclinical hypothyroidism patients. it was 59.18\%(29/49) in overt hypothyroidism patients and 50\%(28/56) in subclinical hypothyroidism patients. Our result were similar to Tayal D et al (2008) ${ }^{9}$ reported that levels of cholesterol increases up to $(50 \%)$ above normal in hypothyroidism and dyslipidemia was more in overt hypothyroidism patients compared to subclinical hypothyroidism patients.

In present study we also found that deranged lipid profile was more in overt hypothyroidism female patients compared to subclinical hypothyroidism female patients. Abnormal total chol., TG, LDL and VLDL was seen in $35.1 \%, 27.0 \%, 8.1 \%$ and $13.5 \%$ in overt hypothyroidism female patients while in subclinical female hypothyroidism patients it was $28.8 \%, 24.4 \%, 8.8 \%, 11.1 \%$ and $15.5 \%$ similar to Gomo $\mathbf{Z}$ et al $\mathbf{( 1 9 9 4 )}^{\mathbf{1 0}}$ in their study they show The lipids and lipoproteins distribution showed a significant increase in total cholesterol and LDL-C levels in the patient group. In contrast the HDL-C and its subfractions (HDL2-C and HDL3-C) were significantly lower in the patient groups.

\section{Hypothyridism With Gall Stone}

In presenting study we found that prevalence of gall stone was more common in subclinical hypothyroidism patients compared to overt hypothyroidism patients which was $15 / 56(26.78 \%)$, and $7 / 49$ (14.28\%) respectively. Our result similar to Laukkarinen $\mathbf{J}$ et al $\mathbf{( 2 0 0 3})^{\mathbf{1 1}}$ also found in their study that prevalence of subclinical hypothyroidism was $11.4 \%$ in CBD stone. In presenting study we found that prevalence of gall stone was more in female compared to male in both subclinical and overt hypothyroidism patients. Which was $28.8 \%(13): 18.18 \%(2)$ in subclinical and $18.9 \%(7): 0(0 \%)$ in overt hypothyroidism patients. In our study we found that most of the patients who have gall stone were in between 40-60 year age group both in subclinical and overt hypothyroidism which was $9(16.35 \%)$ and $4(8.16 \%)$ respectively. While in $>60$ year age group it was 5(8.92\%) and $3(6.12 \%)$. There is a significant association between the common bile duct stones and previously diagnosed hypothyroidism.

\section{Hypothyridism With Other Co-Morbidites}

Presenting study showing that comorbidities were more common in female hypothyroidism patients compared to male hypothyroidism patients. Out of 82 female hypothyroidism patients 28 were hypertensive and 4 were diabetic and 4 had coronary artery disease while in out of 23 male hypothyroidism patients 9 were hypertensive and no diabetic and 6 had coronary artery disease. In our study we also found that co-morbidities like hypertension, diabetes and coronary artery disease (CAD) was common in subclinical hypothyroidism patients compared to overt hypothyroidism.

\section{Conclusion}

The study entitled "Study of lipid profile in patients of hypothyroidism and correlation with incidence of gall stone". This study included 105 patients of hypothyroidism attending the outdoor and indoor facilities in G.R. Medical College, Gwalior. Our study revealed that 
- Hypothyroidism is more common in female than male and also more in the age group between 41-60 yrs.

- Commonest symptoms of hypothyroidism found in tiredness, weight gain, constipation and abdominal pain in order of predominant while commonest signs are edema, dry coarse skin, pallor, bradycardia, anemia in both males and females.

- Hypothyroidism is associated with dyslipidemia characterized by elevated total $\mathrm{CH}, \mathrm{LDL}-\mathrm{CH}, \mathrm{TG}$ and low HDL and so it is an independent risk factor for atherosclerosis \& coronary artery diseases. Overt hypothyroidism patient have significantly higher dyslipidemia compared to subclinical hypothyroidism.

- Cholelithesis is common with hypothyroidism patients and incidence of gall stone is more in subclinical hypothyroidism patients which is statistically significant.

- Further studies is needed to investigate to whether early treatment of hypothyroidism could prevent gall stone, dyslipidemia \& other comorbid illness in these patients.

\section{References}

[1]. Larry J, Anthony P. Disorders of thyroid glands. In: "Harrison's Principles of Internal Medicine", Fauci, Kasper, Hauser, Longo, Jameson, Loscalzo, editors. 17 th edition,Vol Il. Mc Graw Hill; 2008, pp 222447.

[2]. William F.Ganong. The thyroid gland. In: "Review of Medical Physiology, 22th edition. Mc Graw Hill;2003, pp 317 331.

[3]. Reed P, Terri F. Thyroid. In "Williams Textbook of Endocrinology", 10th edition. Elsevier; 2003, pp 331 73.

[4]. Galesanu C, Lisnic N, Teslaru R, Apostu L, Zbranca E. Lipids profile in a group of hypothyroid patients vs treated hypothyroid patients. Rev Med Chir Soc Med Nat Iasi 2004 Jul-Sep;108(3):554-60.

[5]. Irfan M. Khurram, Kiran S. Choudhary, Khan Muhammad, Najmul Islam. Clinical presentation of hypothyroidism: A case control analysis. J Ayub Med Coll Abbottabad 2003;15(1)

[6]. B.B. Samanta. Clinical profile of hypothyroidism. Physician, S.E. Railway polytclic at : Motibagh, P.O. Bezobagh, nagpur-440004, Maharashtra.

[7]. Rosemarie A Wright-Pascoe. Clinical features of spontaneous hypothyroidism in one physician's practice in Jamaica. Int $\mathrm{J}$ Gen Med. 2010 May 26;3:137-41.

[8]. Lahiri, D., Dasgupta A., Kundu S. - Menstrual pattern and fertility status in hypothyroid women. Journal of Obstetrics and Gynaecology of India. Vol. 46:p-663-671, 1996.

[9]. D Tayal, B Goswami, VK Gupta, V Mallika. Evaluation of lipid profile in hypothyroid patients : Our experience. Thyroid Res Tract 2008;5(2):43-7.

[10]. Gomo Z, Ascott MB. The association of serum thyroid stimulating hormone and serum lipids and lipoproteins in patients with suspected hypothyroidism. Cent Afr J Med 1994;40(4):94-8.

[11]. Johanna Laukkarinen, Gediminas Kiudelis, Marko Lempinen, Sari Raty, Hanna Pelli et al. Increased prevalence of subclinical hypothyroidism in common bile duct stone patients. J Clin Endocrinol Metab 2007;92:4260-4264. 